\title{
Lovastatin as a supplement to mitigate rumen methanogenesis: an overview
}

\author{
Amaury Ábrego-Gacía ${ }^{1,2}$, Héctor M. Poggi-Varaldo ${ }^{1,2 *}$, Vania Robles-González ${ }^{3}$, Teresa Ponce-Noyola', \\ Graciano Calva-Calva ${ }^{1}$, Elvira Ríos-Leal ${ }^{1}$, Daniel Estrada-Bárcenas ${ }^{4}$ and Alfredo Mendoza-Vargas ${ }^{5}$
}

\begin{abstract}
Methane from enteric fermentation is the gas with the greatest environmental impact emitted by ruminants. Lovastatin (Lv) addition to feedstocks could be a strategy to mitigate rumen methane emissions via decreasing the population of methanogenic archaea (MA). Thus, this paper provides the first overview of the effects of LV supplementation, focusing on the inhibition of methane production, rumen microbiota, and ruminal fermentation. Results indicated that Lv treatment had a strong anti-methanogenic effect on pure strains of MA. However, there are uncertainties from in vitro rumen fermentation trials with complex substrates and rumen inoculum. Solid-state fermentation (SSF) has emerged as a cost-effective option to produce LV. In this way, SSF of agricultural residues as an LV-carrier supplement in sheep and goats demonstrated a consistent decrease in ruminal methane emissions. The experimental evidence for in vitro conditions showed that LV did not affect the volatile fatty acids (VFA). However, in vivo experiments demonstrated that the production of VFA was decreased. LV did not negatively affect the digestibility of dry matter during in vitro and in vivo methods, and there is even evidence that it can induce an increase in digestibility. Regarding the rumen microbiota, populations of MA were reduced, and no differences were detected in alpha and beta diversity associated with Lv treatment. However, some changes in the relative abundance of the microbiota were induced. Further studies are recommended on: (i) Lv biodegradation products and stability, as well as its adsorption onto the solid matter in the rumen, to gain more insight on the "available" or effective Lv concentration; and (ii) to determine whether the effect of LV on ruminal fermentation also depends on the feed composition and different ruminants.
\end{abstract}

Keywords: Fermentation, Lovastatin, Methanogenesis, Microbiota, Rumen

\section{Introduction}

Recently, the contribution of the ruminant livestock sector to greenhouse gas (GHG) emissions has become of concern and increasingly crucial for animal and environmental scientists. The main GHGs of this sector are methane $\left(\mathrm{CH}_{4}\right)$ and nitrous oxide $\left(\mathrm{N}_{2} \mathrm{O}\right)$ [1, 2]. Methane emitted by livestock from enteric fermentation is the gas with the greatest environmental impact. From a climate

\footnotetext{
* Correspondence: lazarillodetormes1001@gmail.com; r4cepe@yahoo.com ${ }^{1}$ Department of Biotechnology and Bioengineering, CINVESTAV-IPN, P.O.Box 17-740, 07000 Mexico City, Mexico

${ }^{2}$ Environmental Biotechnology and Renewable Energies Group, CINVES TAV-IPN, P.O.Box 17-740, 07000 Mexico City, Mexico

Full list of author information is available at the end of the article
}

change point of view, $\mathrm{CH}_{4}$ has been reported to be the most abundant GHG other than $\mathrm{CO}_{2}$ [3]. The magnitude estimation of $\mathrm{CH}_{4}$ compared to $\mathrm{CO}_{2}$ differs based on its higher global warming potential (28 times over a 100-year-time horizon) and shorter atmospheric lifetime, which is about 12.4 years [4]. Global GHG emissions from the livestock sector from 1995 to 2005 were between 5.6 and 7.5 gigatons of $\mathrm{CO}_{2}$ eq./year and represented $\sim 14.5 \%$ of the global anthropogenic GHG emissions $[2,5]$. Furthermore, worldwide enteric methane emissions were estimated to be approximately 111 $\mathrm{Tg} /$ year and contributed almost one-third of global anthropogenic emissions [4].

(c) The Author(s). 2021 Open Access This article is licensed under a Creative Commons Attribution 4.0 International License, which permits use, sharing, adaptation, distribution and reproduction in any medium or format, as long as you give appropriate credit to the original author(s) and the source, provide a link to the Creative Commons licence, and indicate if changes were made. The images or other third party material in this article are included in the article's Creative Commons licence, unless indicated otherwise in a credit line to the material. If material is not included in the article's Creative Commons licence and your intended use is not permitted by statutory regulation or exceeds the permitted use, you will need to obtain permission directly from the copyright holder. To view a copy of this licence, visit http://creativecommons.org/licenses/by/4.0/ The Creative Commons Public Domain Dedication waiver (http://creativecommons.org/publicdomain/zero/1.0/) applies to the data made available in this article, unless otherwise stated in a credit line to the data. 
The main end-products of ruminal fermentation besides methane are volatile fatty acids (VFA) and microbial protein. These products are absorbed in the digestive system and incorporated into the metabolism of the animal host [6]. However, some fermentation end-products $\left(\mathrm{CO}_{2}\right.$ and $\left.\mathrm{H}_{2}\right)$ are not absorbed in the rumen. In this case, $\mathrm{CO}_{2}$ and $\mathrm{H}_{2}$ are consumed by methanogenic archaea (MA) to produce methane, which the animals release into the atmosphere [7]. Also, it is considered that around $2 \%$ to $12 \%$ of the total energy consumed by ruminants can be metabolized to $\mathrm{CH}_{4}$ [8].

Researchers have investigated various approaches to mitigate ruminal methane emissions and enhance livestock productivity aiming for sustainable development $[9,10]$. In this context, Lovastatin (Lv) is a competitive inhibitor of the HMG-CoA reductase enzyme (3-Hydroxy-3-methylglutaryl CoA reductase) [11]. The latter is the rate-limiting enzyme for the mevalonate pathway required for the biosynthesis of polyprenols, which have a significant role in maintaining the function and structure of the MA membrane [12].

Therefore, this paper provides the first overview of the effects of Lv supplementation, focusing on the inhibition of methane production, rumen microbiota, and ruminal fermentation.

The manuscript critically examines the role of $\mathrm{Lv}$ in the following topics: (i) inhibition of MA, (ii) in vitro and in vivo ruminal methane mitigation trials, (iii) the pattern of change in rumen fermentation and digestibility, and (iv) shifts in the rumen microbiota.

\section{Lovastatin as a strategy to inhibit methanogenic archaea}

Several strategies to mitigate rumen methane emissions have been developed, such as nutrition (lipid supplementation, concentrate based diets), chemical inhibitors (3nitrooxypropanol, 10-anthraquinone, nitroethane), secondary plant compounds (tannins, flavonoids, saponins), and Lv addition to the feedstocks of ruminants, among others. One crucial issue that could dictate the adoption and success of such strategies is their feasibility of application at the farm level $[9,10,13]$.

Furthermore, the adaptive capabilities of livestock production systems must prioritize profitability and food safety to adopt a methane reduction strategy [5]. In this regard, modulation of the rumen is an option for inhibiting methanogens [14].

It is known that the membranes of MA and eubacteria generally consist of a double-layer or a monolayer of lipid molecules where proteins can float [15]. Unlike eubacteria and eukaryotes, the lipid composition of the archaea consists of chains of isoprenoids linked to the sn-glycerol-1-phosphate backbone by ether bonds [16]. It has been reported that the fundamental unit of archaea membrane lipids could undergo an intermolecular dimerization building a diglycerol-linked pair of C40 isoprenoid hydrocarbon. The archaea membrane synthesizes complex isoprenoid ether lipids (Fig. 1a), which are unique features of the domain archaea [18]. As a result, a strategy to inhibit the growth of MA is via compounds that inhibit the activities of some key enzymes linked to the synthesis of isoprene units.

Statins are MG-CoA reductase inhibitors that catalyze the conversion of HMG-CoA to mevalonic acid (Fig. 1b) $[19,20]$. The latter is the pathway for synthesizing isopentenyl pyrophosphate and its isomer dimethylallyl pyrophosphate, important precursors of molecules such as isoprenoids, cholesterol, and terpenes [17, 21].

Statins are categorized into three categories: $(i)$ natural statins, which are produced mainly by fungal fermentation, for instance, Lv and pravastatin, (ii) semi-synthetic statins that are derived from a natural statin by chemical synthesis here include simvastatin, and (iii) synthetic statins which cannot be naturally produced or by chemical synthesis of natural statins, e.g., rosuvastatin, pitavastatin, atorvastatin, fluvastatin, and cerivastatin. Those statins contain two units, i.e., a chiral 3,5-syn-diol acid and a chiral $\beta$-hydroxy- $\gamma$-lactone (alternatively its open-chain analog) $[20,22]$.

Among the statins, Lv has attracted great interest as an anti-methanogenic compound. It is a nonhygroscopic crystalline powder, has the empirical formula $\mathrm{C}_{24} \mathrm{H}_{36} \mathrm{O}_{5}$, a molecular weight of $404.5 \mathrm{~g} / \mathrm{mol}$, and its water solubility is $0.4 \mathrm{mg} / \mathrm{L} \mathrm{[19]}$. It is soluble in $\mathrm{N}$ dimethylformamide and acetone; it is highly soluble in $\mathrm{CHCl}_{3}$. Lv exhibits moderate solubilities in methanol, ethanol, acetonitrile, and isopropanol [23].

The research to date has demonstrated that Lv inhibits MA by two pathways. The first is related to the cell membrane; MA contain long chains of isoprenoid ether lipids as the main components of the cell membrane, which are synthesized via the mevalonate pathway where HMG-CoA reductase acts as the rate-limiting enzyme [24]. Lv inhibits HMG-CoA reductase, thus disrupting the cell membrane synthesis of MA and impeding the membrane-bound electron transport of the pathway for methane production [25]. Finally, the growth of methanogens was negatively affected $[26,27]$.

The second effect of Lv on inhibition of MA is associated with the $\mathrm{F}_{420}$ coenzyme. Several oxidation/reduction reactions are involved in the metabolism of methanogens, which require different oxidoreductase enzymes, some of which participate in the electron transfer during the methanogenesis pathway. For instance, Sharma et al. [28] reported in a prediction model for NADP oxidoreductase inhibition in the Methanobrevibacter smithii strain that $\mathrm{Lv}$ and mevastatin showed a 
a)



3-Hydroxy-3-methylglutaryl-CoA

HMG-CoA reductase

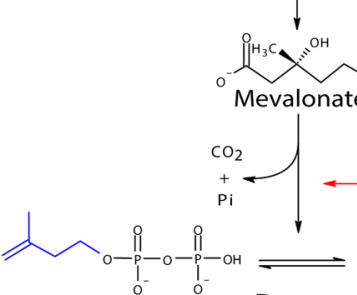

Isopentanyl pyrophosphate

(IPP)<smiles>CC(C)=CCC/C(C)=C/COP(=O)([O-])OP(=O)([O-])O</smiles>

Geranyl pyrophosphate (GPP)

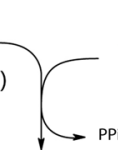

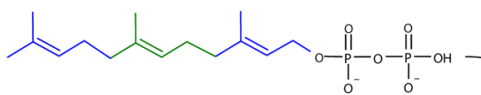
Farnesyl pyrophosphate (FPP)

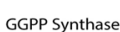

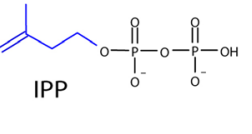



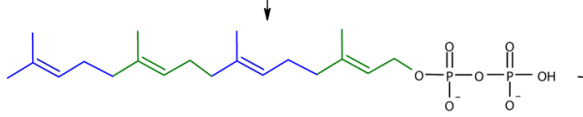

Geranylgeranyl diphosphate (GGPP)

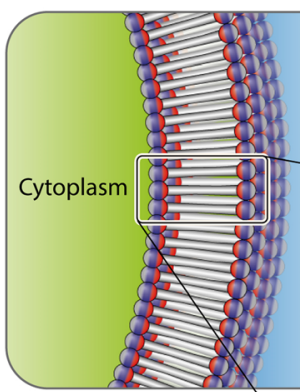

llylpyropho



3-Hydroxy-3-methylglutaryl-CoA

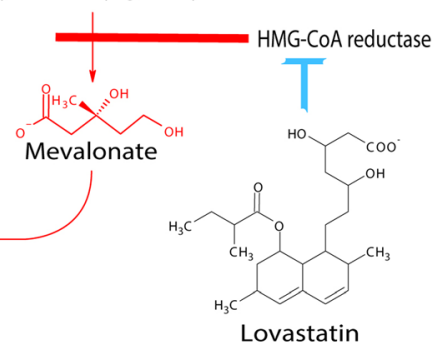

Lovastatin<smiles>C=C(C)CCOP(=O)([O-])OP(=O)([O-])O</smiles>

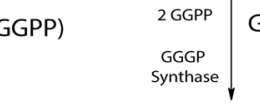

Glyceryl-Sn-1-phosphate (G1P)





2,3-di-O-Geranylgeranyl-sn-glyceryl-1-phosphate (2,3-diGG-Sn-G-1-P)

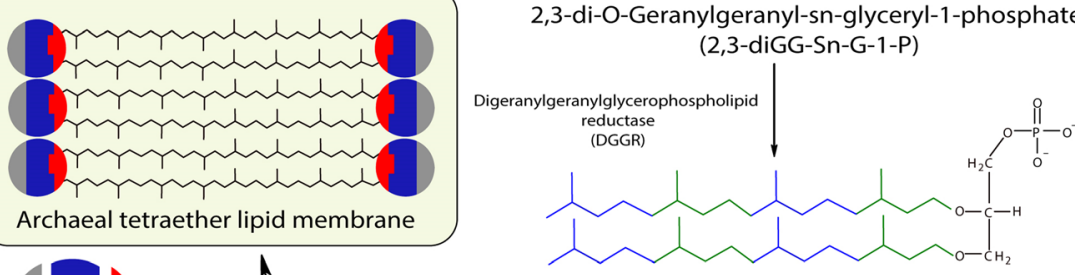

2,3-di-O-Phytanyl-sn-glyceryl-1-phosphate (2,3-diGG-Sn-G-1-P)

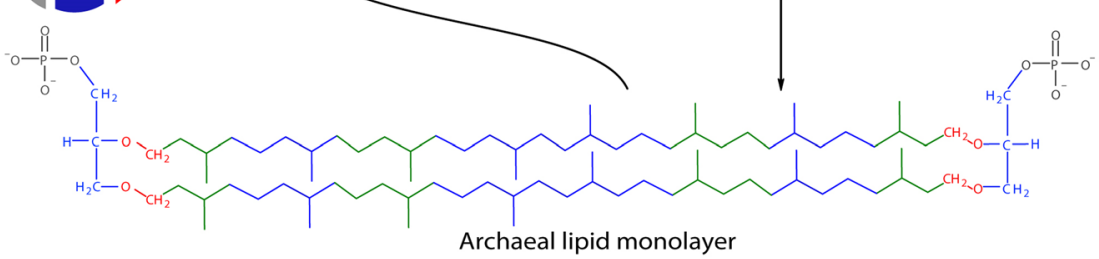

Fig. 1 Biosynthesis of archaea membrane ether lipids. a Mevalonate pathway and archaeal lipid synthesis. b Inhibitory effect of the lovastatin on HMG-CoA reductase, the rate-limiting enzyme in the conversion of HMG-CoA to Mevalonate $[12,17]$ 
higher affinity for this enzyme than the $\mathrm{F}_{420}$ coenzyme. So, statins could inhibit the activity of the NADP oxidoreductase protein dependent on the $\mathrm{F}_{420}$ coenzyme, an electron carrier in the methanogenesis pathway. However, the experimental evidence on this issue is still unclear, and the number of studies considered is small $[28,29]$.

\section{Effect of lovastatin on ruminal methane production}

$\mathrm{Lv}$ is widely indicated for the treatment of hypercholesterolemia in humans [11]. The cost of Lv is approximately 7.5 US $\$ / g$ of industrial-grade ([30], SigmaAldrich, St. Louis MO, USA). Consequently, its use in animal feeding is restricted [26], and some cost-effective alternatives to produce Lv have been evaluated. For instance, Lv production by solid-state fermentation (SSF) has emerged as a suitable option [31].

The SSF and the fermented substrates applied to mitigate rumen methanogenesis have the following advantages [32, 33]: (i) lignocellulosic agricultural residues used for SSF are inexpensive, readily available in farms, and commonly utilized for livestock feeding, ( $i i)$ the fermented substrates should be utilized without pretreatment reducing polluting discharges to the environment from the Lv extraction process, and (iii) it can give highquality yields of secondary metabolites and cellulolytic enzymes.

Several agricultural residues have been assessed as a substrate to produce Lv by SSF, but in this review, only the results of SSF trials where fermented agricultural residues were used to inhibit the methanogenesis are discussed. Interestingly, all strains tested belonged to $A s$ pergillus terreus. The SSF of rice straw gave $\mathrm{Lv}$ yields of 0.26 and $0.69 \mathrm{mg} / \mathrm{g}$ DM [34, 35]. Despite the high-fiber content of rice straw, the Lv productivity was close to that of rice grain $(0.57 \mathrm{mg} / \mathrm{g} \mathrm{DM})$ [36]. Another substrate in SSF for this target was palm kernel cake (PKC) which resulted in the maximum production of $0.85 \mathrm{mg} / \mathrm{g}$ DM [37], and finally, the oat straw, which was the highest $\mathrm{Lv}$ yield $(23.8 \mathrm{mg} / \mathrm{g} \mathrm{DM})$ [31]. These results generally suggest low to moderate Lv yields compared to the findings of experiments devoted to statins production [30].

\section{In vitro experiments}

Table 1 summarizes the in vitro rumen fermentation data associated with methane mitigation by pure $\mathrm{Lv}$ or fermented residues as an Lv-carrier treatment.

The addition of $\mathrm{Lv}$ provides reliable evidence of complete inhibition of methane formation by cultured methanogens. Miller and Wolin [26] evaluated the addition of pure Lv $(4 \mathrm{mg} / \mathrm{mL})$ on strains of the Methanobrevibacter genus co-cultured with fibrinolytic/cellulolytic bacteria. This dose decreased the growth of the Methanobrevibacter as well as $\mathrm{CH}_{4}$ production. These results were confirmed by Demonfort et al. [38], who reported for pure cultures of MA and bacteria from the human digestive system that methanogenesis was inhibited entirely at the same concentration of $\mathrm{Lv}(4 \mathrm{mg} / \mathrm{mL})$. This view also was supported by Jahromi et al. [27], who found that methane production of Methanobrevibacter smithii strain was inhibited by $96 \%$ with an Lv dose of $50 \mathrm{mg} / \mathrm{mL}$, under similar cultivation conditions to those in the previous research.

Unfortunately, there is no general agreement about the effects of pure Lv on in vitro trials using rumen fluid inoculum (RFI) and forages as well as total mixed rations. First, Busquet et al. [39] evaluated a diet with forage to concentrate (f:c) ratio of 50:50, RFI from a dairy cow, and a dose of $\mathrm{Lv}$ of $5 \mathrm{mg} / \mathrm{L}$. There was no significant reduction of methane production between treatment and control groups. These results agreed with those of other studies that reported no effects of $\mathrm{Lv}$ (at dose $3.2 \mathrm{mg} / \mathrm{L}$ ) on methanogenesis with grass silage and barley grain ration of (50:50) as substrate and RFI from steers [41]. A possible explanation for these results may be the low Lv dosage; it was initially proposed that methane inhibition was highly significant at $4 \mathrm{mg} / \mathrm{L}$ [26] but, this dose was based on pure cultures of MA without substrate and RFI. However, the addition of simvastatin (purity $>97 \%$ ) at a low dose of $10 \mathrm{mg} / \mathrm{L}$ reduced the in vitro rumen methanogenesis only by a poor $9.3 \%$ using a high forage diet $(P<0.05)$ [43]. The latter is the only article research that reported the antimethanogenic effect of a low-dosage statin with RFI and a diet to the best of our knowledge.

The role of the presence of solids in the ruminal fermentation tests as well as the complex composition of dissolved and colloidal organic matter could affect the Lv availability for inhibiting the MA possibly due to the well-known phenomenon of hysteresis that characterizes the interaction of soluble organic compounds and organic particles in soils and sediments in the field of remediation $[44,45]$. For instance, there is no information on the possible extent of adsorption of Lv onto the solids (e.g., from diets) present in the complex medium (and the opposite process of desorption). If adsorption of Lv were significant, then the Lv concentration available for inhibiting the MA would be a small fraction of the added dosage of $\operatorname{Lv}[46,47]$. That is, there would be a "sequestration" of Lv that undoubtedly would decrease its inhibitory effect.

In contrast to earlier findings, Soliva et al. [40] observed a $40 \%$ inhibition of methane production in an experiment using the "rumen simulation technique." They used a substrate that consisted of a diet based on barley, ryegrass hay, and soybean, RFI from a dairy cow, and a pure $\mathrm{Lv}$ dose of $150 \mathrm{mg} / \mathrm{L}$. The inhibition level observed was consistent with the methane mitigation by pure 
Table 1 Effect of lovastatin on in vitro ruminal methane production

\begin{tabular}{|c|c|c|c|c|c|}
\hline Source of Lv & $\begin{array}{l}\text { Donor animals and } \\
\text { experimental diet }\end{array}$ & In vitro gas production technique & $\begin{array}{l}\mathrm{Lv}, \\
\mathrm{mg} / \mathrm{L}\end{array}$ & $\begin{array}{l}\text { Methane } \\
\text { Inhibition, } \\
\%\end{array}$ & Reference \\
\hline \multicolumn{6}{|c|}{ Pure cultures of methanogenic archaea } \\
\hline Sigma-Aldrich, St Louis, MO, USA & & $\begin{array}{l}\text { Technique: Hungate tubes } \\
\text { Culture medium: BRN } \\
\text { Inoculum: Methanobrevibacter strains }\end{array}$ & 4 & 99 & [26] \\
\hline Fermented rice straw extracts & & $\begin{array}{l}\text { Technique: serum bottles } \\
\text { Culture medium: Balch } 1 \text { (DSMZ, Germany) } \\
\text { Inoculum: M. smitthii }\end{array}$ & 50 & 100 & {$[27]$} \\
\hline Sigma-Aldrich, St Louis, MO, USA & & $\begin{array}{l}\text { Technique: Hungate tubes } \\
\text { Culture medium: } S A B \\
\text { Inoculum: M. smitthii }\end{array}$ & 4 & 100 & {$[38]$} \\
\hline \multicolumn{6}{|l|}{ Ruminal-based inoculum and diets } \\
\hline Sigma-Aldrich, St Louis, MO, USA & $\begin{array}{l}\text { Ruminant: bovine } \\
\text { Diet: f:c }{ }^{a} \text { ratio of (50:50) }\end{array}$ & $\begin{array}{l}\text { Technique: fermentation bottles } \\
\text { Substrate: diet with a f:c ratio of (50:50) } \\
\text { Inoculum: ruminal fluid }\end{array}$ & 5 & $N S^{b}$ & [39] \\
\hline $\begin{array}{l}\text { Sigma-Aldrich, GmbH, Buchs, } \\
\text { Switzerland }\end{array}$ & $\begin{array}{l}\text { Ruminant: bovine } \\
\text { Diet: hay, ryegrass, and } \\
\text { concentrate }\end{array}$ & $\begin{array}{l}\text { Technique: RUSITEC system } \\
\text { Substrate: diet with a f:c ratio of (50:50) } \\
\text { Inoculum: ruminal fluid }\end{array}$ & 150 & 40 & {$[40]$} \\
\hline Fermented rice straw & $\begin{array}{l}\text { Ruminant: bovine } \\
\text { Diet: f:c ratio of ( } 40: 60)\end{array}$ & $\begin{array}{l}\text { Technique: calibrated glass syringes } \\
\text { Substrate: fermented rice straw } \\
\text { Inoculum: ruminal fluid }\end{array}$ & 4.3 & 24 & {$[34]$} \\
\hline Sigma-Aldrich, St Louis, MO, USA & $\begin{array}{l}\text { Ruminant: bovine } \\
\text { Diet: f:c ratio of }(60: 40)\end{array}$ & $\begin{array}{l}\text { Technique: serum bottles } \\
\text { Substrate: diet with a f:c ratio of (50:50) } \\
\text { Inoculum: ruminal fluid }\end{array}$ & 3.2 & NS & {$[41]$} \\
\hline Fermented rice & $\begin{array}{l}\text { Ruminant: sheep } \\
\text { Diet: hay }\end{array}$ & $\begin{array}{l}\text { Technique: Hungate tubes } \\
\text { Substrate: fermented rice } \\
\text { Inoculum: ruminal fluid }\end{array}$ & 40 & 9.6 & {$[36]$} \\
\hline $\begin{array}{l}\text { Fermented purple } \\
\text { corn stover }\end{array}$ & $\begin{array}{l}\text { Ruminant: dairy steers } \\
\text { Diet: no reported }\end{array}$ & $\begin{array}{l}\text { Technique: serum bottles } \\
\text { Substrate: fermented purple corn cob } \\
\text { Inoculum: ruminal fluid }\end{array}$ & 29.5 & 14.6 & {$[42]$} \\
\hline $\begin{array}{l}\text { Fermented } \\
\text { Oat straw }\end{array}$ & $\begin{array}{l}\text { Ruminant: bovine } \\
\text { Diet: f:c ratio of (60:40) }\end{array}$ & $\begin{array}{l}\text { Technique: serum bottles } \\
\text { Substrate: diet with a f:c ratio of (30:70) } \\
\text { Inoculum: ruminal fluid }\end{array}$ & 150 & 38 & {$[31]$} \\
\hline $\begin{array}{l}\text { Simvastatin, Sigma-Aldrich, Prague, } \\
\text { Czech Republic }\end{array}$ & $\begin{array}{l}\text { Ruminant: bovine } \\
\text { Diet: f:c ratio of ( } 70: 30)\end{array}$ & $\begin{array}{l}\text { Technique: serum bottles } \\
\text { Substrate: diet with a f:c ratio of (64:36) } \\
\text { Inoculum: ruminal fluid }\end{array}$ & 100 & 26.2 & {$[43]$} \\
\hline
\end{tabular}

${ }^{a}$ Forage: concentrate ratio

${ }^{\mathrm{b}}$ Non-significant

simvastatin $100 \mathrm{mg} / \mathrm{L}(P<0.05)$ incubated with a $70 \%$ forage diet and RFI [43].

On the other hand, the experiments with agricultural residues as Lv-carriers showed the following results. Jahromi et al. [34] reported a $24 \%$ inhibition of $\mathrm{CH}_{4}$ formation with fermented rice straw (concentration of Lv, $4.32 \mathrm{mg} / \mathrm{L}$ RFI medium). A later study claimed that fermented purple corn stover ( $\mathrm{Lv}$ dosage was $29.5 \mathrm{mg} / \mathrm{L}$ RFI medium) had a minor effect on decreasing methane production by $14.6 \%$ [42]. As noted above, in both cases, the fermented agricultural residues as Lv-carriers were used as the only substrate for in vitro rumen fermentation trials.

Recent evidence suggested that replacement of ordinary oat straw (18.9\% and $28.4 \%)$ with fermented oat straw as an Lv-carrier to achieve initial doses of 100 and $150 \mathrm{mg} \mathrm{Lv} / \mathrm{L}$ in the RFI medium with a high-grain ration led to mitigating methane production by $38 \%$ under in vitro conditions [31]. It should be noted that this is the first work where a fermented agricultural residue (Lv-carrier) was supplemented to a total mixed ration (Table 1).

The results suggest that there could be a threshold effect of pure Lv on in vitro methane production . Likely, this level would be $100 \mathrm{mg} / \mathrm{L}$ [31, 40, 43]. Below this threshold, no significant difference seemed to be detected. In contrast, beyond that threshold, the methanogenesis inhibition holds. One could speculate whether this threshold would be related to possible adsorption of $\mathrm{Lv}$ onto solids of the RFI medium, thus decreasing Lv availability by the MA $[46,47]$. As suggested above, it would be helpful to conduct more research to distinguish between adsorbed and free Lv in the RFI medium. 


\section{In vivo experiments}

Experiments under in vivo conditions related to Lv have mainly focused on the anti-methanogenic effects of the dietary fermented rice straw as an Lv carrier at different concentrations in ruminants (Table 2). Reported results in the open literature are scarce for large ruminants.

Only one article has been published in the scientific literature with beef cattle as an animal model. RamírezRestrepo et al. [49] evaluated a basal diet supplemented with four increasing levels of red yeast rice (RYR) as a source of $\mathrm{Lv}$ on dry matter (DM) intake, live weight (LW) gain, and $\mathrm{CH}_{4}$ emissions from cattle. The findings of this study suggest a decrease of $\mathrm{CH}_{4} \mathrm{~g} / \mathrm{kg} \mathrm{DM}$ intake by $14.5 \%$ with RYR $(40 \mathrm{~g} / \mathrm{d}$ to give a dose of $\mathrm{Lv}, 0.92 \mathrm{mg} /$ $\mathrm{kg} \mathrm{LW}$ ) in a diet f:c ratio of 15:85. However, the DM intake decreased by approximately $50 \%$ after 6 days of RYR supplementation with higher levels of RYR (110 and $120 \mathrm{~g} / \mathrm{d}$ ), which represented $\mathrm{Lv}$ doses of 2.62 and $2.88 \mathrm{mg} / \mathrm{kg} \mathrm{LW}$, respectively. The authors also reported ruminant digestive, muscular, and urinary system disorders that disappeared 3 days after the RYR treatment was withdrawn, although the authors ascribed those disorders to unknown metabolites of Monascus purpureus during the rice fermentation, not the Lv.

Regarding research on small ruminants, Morgavi et al. [36] evaluated the anti-methanogenic effect of fermented rice as an $\mathrm{Lv}$-carrier to obtain a dose of $\mathrm{Lv} 2.26 \mathrm{mg} / \mathrm{kg}$ LW, with a diet based on fermented rice and hay (ratio, 50:50). This study showed that the production of rumen methane ( $\mathrm{g} / \mathrm{kg}$ DM intake) was decreased by $30 \%$ in sheep. This is in complete agreement with the findings of other studies, in which the effects of Lv produced by SSF on ruminal methanogenesis were examined. First, Mohd Azlan et al. [35] reported a decrease in rumen $\mathrm{CH}_{4}$ production $(-42 \%)$ when rice straw $(40 \%)$ was replaced by fermented rice straw in the experimental diet of goats (dose of $\mathrm{Lv} 4.14 \mathrm{mg} / \mathrm{kg} \mathrm{LW}$ ). Candyrine et al. [37] determined that fermented PKC had a lower ruminal methane inhibition $(-20 \%)$ when mixed in diets with an f:c ratio of 50:50 and doses of Lv 4 and $6 \mathrm{mg} / \mathrm{kg} \mathrm{LW}$ in goats.

Wang et al. [50] evaluated the effect of supplementation of RYR with a dose of Lv $4.34 \mathrm{mg} / \mathrm{kg} \mathrm{LW}$ in a high-forage diet $(70 \%)$ for goats. Their results suggested a slight decrease in methane production $\left(\mathrm{CH}_{4} /\right.$ DM intake, $\mathrm{L} / \mathrm{kg}$ ) of $14 \%$. However, Klevenhusen et al. [48] tested the effect of a dose of commercial Lv (98\% purity) lower than the previous studies (0.94 $\mathrm{mg} / \mathrm{kg} \mathrm{LW}$ ) on the ruminal methane production of a sheep-fed diet containing an f:c ratio of 48:52. Their results showed no significant effects of commercial $\mathrm{Lv}$ on rumen methanogenesis (Table 2).

More recently, the effects of PKC as an Lv-carrier on the skeletal muscles of goats were examined [51]. The goats were fed a ration characterized by an f:c ratio (77: 23) with three proportions of PKC (fermented with $A$. terreus) to provide 2 , 4 , and $6 \mathrm{mg} \mathrm{Lv} / \mathrm{kg} \mathrm{LW}$. This study showed degeneration in goats' selected muscles at the highest level of Lv. It was concluded that supplementing fermented PKC at Lv dose $>4 \mathrm{mg} / \mathrm{kg} \mathrm{LW}$ negatively affected the health and welfare of the treated goats. However, the adverse effects of Lv on the muscles of treated

Table 2 Effect of lovastatin on in vivo ruminal methane emissions

\begin{tabular}{|c|c|c|c|c|c|c|}
\hline \multirow[t]{2}{*}{ Source of Lv } & \multirow[t]{2}{*}{ Animal and experimental diet } & \multirow[t]{2}{*}{$\begin{array}{l}\text { Technique to } \\
\text { estimate rumen } \\
\mathrm{CH}_{4}\end{array}$} & \multirow{2}{*}{$\begin{array}{l}\text { Lv, } \\
\mathrm{mg} / \\
\mathrm{kg} \\
\mathrm{LW}^{\mathbf{b}}\end{array}$} & \multicolumn{2}{|c|}{$\begin{array}{l}\text { Methane } \\
\text { production, } \mathrm{g} \mathrm{CH}_{4} / \\
\mathrm{Kg} \mathrm{DMI}^{\mathrm{a}}\end{array}$} & \multirow[t]{2}{*}{ Reference } \\
\hline & & & & Control & Treatment & \\
\hline $\begin{array}{l}\text { Commercial Lv (98\% purity, Yick-Vic Chemicals \& } \\
\text { Pharmaceuticals Ltd., Hong Kong, China) }\end{array}$ & $\begin{array}{l}\text { Ruminant: Sheep } \\
\text { Diet: } f: c^{c} \text { ratio of }(45: 52)\end{array}$ & $\begin{array}{l}\text { Open-circuit } \\
\text { respiratory } \\
\text { chamber }\end{array}$ & 1.06 & 25.1 & 25.9 & {$[48]$} \\
\hline $\begin{array}{l}\text { Fermented red rice power (Zhejiang Medicines } \\
\text { and Health Products, Hangzhou, China) }\end{array}$ & $\begin{array}{l}\text { Ruminant: Bovine } \\
\text { Diet: f:c ratio of }(15: 85)\end{array}$ & $\begin{array}{l}\text { Open-circuit } \\
\text { respiratory } \\
\text { chamber }\end{array}$ & 0.92 & 20 & 17.1 & {$[49]$} \\
\hline Fermented rice & $\begin{array}{l}\text { Ruminant: Sheep Diet: Based on } \\
\text { rice }(50 \%) \text { and rice hay (50\%) }\end{array}$ & $\begin{array}{l}\text { Sulfur hexafluoride } \\
\text { (SF6) }\end{array}$ & 2.26 & 35.2 & 24.9 & {$[36]$} \\
\hline Red yeast rice & $\begin{array}{l}\text { Ruminant: Goats Diet: } f: c \text { ratio of } \\
(70: 30)\end{array}$ & $\begin{array}{l}\text { Open-circuit } \\
\text { respiratory } \\
\text { chamber }\end{array}$ & 4.34 & 20 & 18.3 & {$[50]$} \\
\hline Fermented rice straw & $\begin{array}{l}\text { Ruminant: Goats Diet f:c ratio of } \\
(40: 60)\end{array}$ & $\begin{array}{l}\text { Open-circuit } \\
\text { respiratory } \\
\text { chamber }\end{array}$ & 4.14 & 60 & 35 & {$[35]$} \\
\hline Fermented palm kernel cake & $\begin{array}{l}\text { Ruminant: Goats } \\
\text { Diet: f:c ratio of }(73: 27)\end{array}$ & $\begin{array}{l}\text { Open-circuit } \\
\text { respiratory } \\
\text { chamber }\end{array}$ & 6 & 24.23 & 19.23 & {$[37]$} \\
\hline
\end{tabular}

${ }^{\mathrm{a}}$ Dry matter intake

bLive weight

cForage:concentrate ratio 
goats cannot be attributed to $\mathrm{Lv}$ per se because the experiment did not test a positive control with pure Lv.

The experiments using fermented agricultural residues as Lv carriers suggested an anti-methanogenic effect on cattle, sheep, and goats with a range of Lv doses of 0.92 to $6 \mathrm{mg} / \mathrm{kg} \mathrm{LW}$ (Table 2). Unfortunately, there are no systematic studies that compare the effect of the same dose of Lv on the ruminal methanogenesis in the significant domestic ruminants (cattle, sheep, and goats) simultaneously. Table 2 shows that an Lv $4 \mathrm{mg} / \mathrm{kg}$ LW dose was evaluated on goats $[35,37]$ but not sheep and cattle. In contrast, the dose of $1 \mathrm{mg} / \mathrm{kg} \mathrm{LW}$ was evaluated on cattle and sheep $[48,49]$ but not on goats. Thus, no firm trends can be appreciated.

Regarding the influence of feed composition on the Lv effects on ruminal fermentation, as highlighted in Table 1 , in vitro trials suggest a trend in the antimethanogenic effect of Lv-dose $(>100 \mathrm{mg} / \mathrm{L})$, which is independent of substrate type either low- or highconcentrate diets. Thus, it seems that there is no effect of the feed composition associated with $\mathrm{Lv}$ as a methane inhibitor treatment [31, 40, 43].

On the other hand, in vivo trials with dietary fermented rice straw showed that Lv concentration higher than $0.92(\mathrm{mg} / \mathrm{kg} \mathrm{LW})$ was associated with methanogenesis inhibition [35, 36, 50]; however, no clear trends on a possible effect of feed composition were found.

It could be recommendable to obtain more experimental evidence on the effect of feed composition when Lv was added, both at in vitro and in vivo studies. The underlying hypothesis would be that feed composition could influence Lv availability, which would have an effect on Lv efficacy in ruminal fermentation.

\section{Effect of lovastatin on fermentation and rumen digestibility}

As far as VFA production is concerned, Wang et al. [50] and Klevenhusen et al. [48] found no significant effects of pure Lv and RYR treatments on the production and profile of VFA in goats and sheep, respectively. It was demonstrated a decrease in acetate molar proportion $(P<0.05)$ and a slight increase in molar proportions of butyrate and propionate when sheep fed fermented rice [36]. Nevertheless, a significant abatement in the butyrate molar proportion was observed when cattle and goats were fed diets with fermented rice straw and RYR as Lv-carriers by Mohd Azlan et al. [35] and RamírezRestrepo et al. [49], respectively.

The effect of Lv on in vitro the VFA pattern has still not been identified (Table 3), the proportion of propionate was increased. In contrast, acetate and butyrate proportions were reduced by simvastatin and atorvastatin at $100 \mathrm{mg} / \mathrm{L}$; the latter also reduced the total VFA $(P<$ 0.05) [43]. However, a similar dose of $\mathrm{Lv}(150 \mathrm{mg} / \mathrm{L}) \mathrm{did}$ not affect the production and profile of VFA, although methanogenesis was inhibited $(P<0.05)$ [40].

Among the key factors that could influence the antimethanogenic effect of Lv, we can distinguish (i) solubility of Lv and availability, (ii) chemical form of $\mathrm{Lv}$, and (iii) stability of Lv.

Table 3 Effects of lovastatin on rumen fermentation variables

\begin{tabular}{|c|c|c|c|c|c|c|c|c|}
\hline $\mathrm{pH}$ & $\mathrm{NH}_{3}-\mathrm{N}$ & Total VFA & Acetate & Propionate & Butyrate & $A: P^{a}$ & Digestibility & Reference \\
\hline \multicolumn{9}{|c|}{ In vitro experiments } \\
\hline$\approx$ & $\approx$ & $\approx$ & $\approx$ & $\approx$ & $\approx$ & $\approx$ & $\approx$ & [39] \\
\hline$\approx$ & $\downarrow$ & $\approx$ & $\uparrow$ & $\downarrow$ & $\approx$ & $N R^{b}$ & $\approx$ & [40] \\
\hline$\uparrow$ & NR & $\approx$ & $\approx$ & $\downarrow$ & $\approx$ & $\approx$ & $\uparrow$ & {$[34]$} \\
\hline$\approx$ & NR & $\approx$ & $\approx$ & $\approx$ & $\approx$ & NR & $\approx$ & [41] \\
\hline NR & NR & $\approx$ & $\downarrow$ & $\approx$ & $\approx$ & $\approx$ & $\approx$ & {$[36]$} \\
\hline$\approx$ & $\uparrow$ & $\approx$ & $\downarrow$ & $\uparrow$ & $\approx$ & NR & $\uparrow$ & {$[42]$} \\
\hline$\approx$ & $N R$ & $\downarrow$ & $\downarrow$ & $\uparrow$ & $\approx$ & $\downarrow$ & NR & [31] \\
\hline$\approx$ & $\approx$ & $\downarrow$ & $\downarrow$ & $\uparrow$ & $\downarrow$ & $\downarrow$ & $\approx$ & [43] \\
\hline \multicolumn{9}{|c|}{ In vivo experiments } \\
\hline$\approx$ & $\approx$ & $\approx$ & $\approx$ & $\approx$ & $\approx$ & $\approx$ & $\approx$ & {$[48]$} \\
\hline NR & NR & $\downarrow$ & $\approx$ & $\approx$ & $\approx$ & $\approx$ & NR & [49] \\
\hline NR & NR & $\downarrow$ & $\downarrow$ & $\approx$ & $\approx$ & $\downarrow$ & NR & [36] \\
\hline NR & $\approx$ & $\approx$ & $\approx$ & $\approx$ & $\approx$ & $\downarrow$ & $\approx$ & [50] \\
\hline NR & NR & $\approx$ & $\approx$ & $\uparrow$ & $\uparrow$ & $\uparrow$ & $\uparrow$ & [35] \\
\hline$\approx$ & NR & $\approx$ & $\approx$ & $\uparrow$ & $\approx$ & $\downarrow$ & $\approx$ & [37] \\
\hline
\end{tabular}

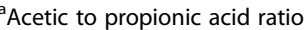

${ }^{\mathrm{b}} N R$, Not reported; $\downarrow$, decreased; $\uparrow$, increased; $\approx$ unchanged 
(i) According to the biopharmaceutical classification system, statins are class II drugs, poorly water-soluble, and high transport thru biological membranes [52]. These factors are associated with Lv anti-methanogenic effectiveness in the rumen ecosystem. In this context, most (in vitro and in vivo) trials were conducted with lipophilic statins, for instance, cerivastatin, atorvastatin, rosuvastatin, Lv, and simvastatin [31, 34, 40, 41]. There was limited evidence of the experiments with hydrophilic statins (pravastatin and rosuvastatin) [43]. Lv can easily cross lipid membranes [25] because of its lipophilicity revealed by a poor water solubility of $0.4 \mathrm{mg} / \mathrm{L}[23$, 52]; however, its biological availability could be negatively affected by its poor water solubility.

(ii) Another issue that our research group has noted is the dosage form of Lv in ruminal fermentation experiments (Fig. 2): the pure Lv commonly is in lactone form "prodrug" and water-insoluble [54]; there are some ways to activated into its $\beta$-hydroxy acid and water-soluble form [55]. However, the studies of ruminal fermentation when pure Lv inhibits methanogenesis did not report Lv chemical activation. Thus, it can be speculated that Lv $\beta$-hydroxy could be a better alternative to mitigate rumen methane, at least in short-term trials.

On the other hand, the fungal SSF produced up to $90 \%$ of Lv $\beta$-hydroxy acid form [53]; as a result, higher availability of active metabolite Lv in the rumen medium is expected. This difference in Lv chemical form appears to explain better results in favor of agricultural residues as Lv-carriers for treating methane mitigation in ruminants.

(iii) Another factor is the stability of Lv during the ruminal fermentation trials. Although in vitro tests last 3 days or less, possible degradation of Lv and the associated decrease of its concentration could occur in this period. Recent evidence suggests that human gut anaerobes catalyzed the conversion of Lv lactone into Lv $\beta$ hydroxy acid [38]. Interestingly, Beltrán et al. [56] demonstrated that Lv incubated in phosphate buffer solution with similar conditions to those of the rumen environment such as temperature $37^{\circ} \mathrm{C}, \mathrm{pH} 7$, in the absence of microbiota (abiotic control), resulting in the transformation of Lv lactone into its $\beta$-hydroxy acid form. Moreover, the authors demonstrated that experiments of human gut spiked with Lv $\beta$-hydroxy acid form could transform the latter to other unknown metabolites.

Unfortunately, stability studies of Lv and its chemical forms in ruminal medium and fermentation conditions are lacking.

In terms of in vivo digestibility studies associated with the anti-methanogenic activity of Lv, small sample sizes are a limitation on this issue (Table 3). Moreover, most of these experiments used fermented agricultural residues as Lv-carriers. Wang et al. [50] reported that the

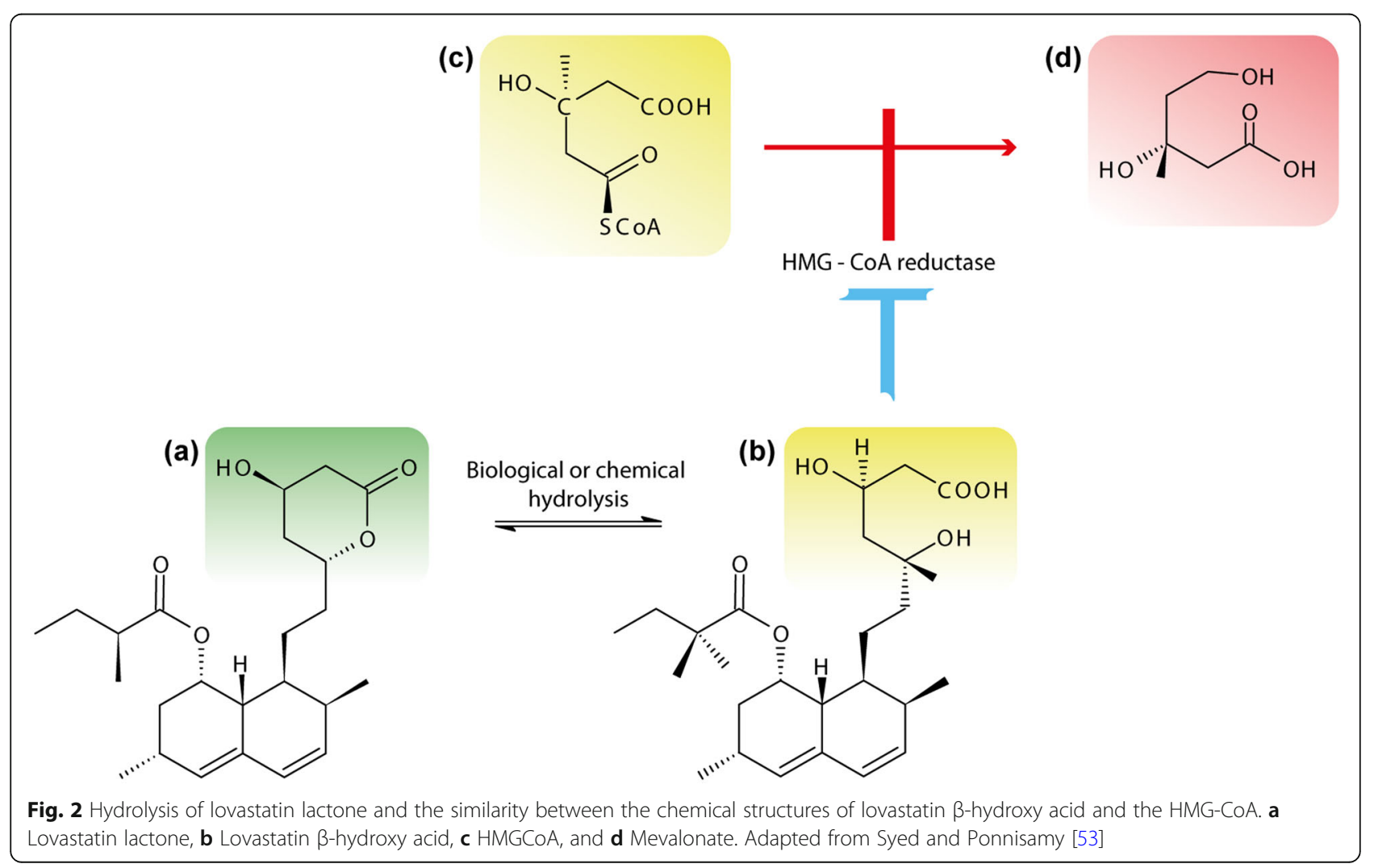


DM digestibility was not significantly affected by replacing rice straw $(8.2 \%)$ with fermented rice straw to obtain a dose of $\mathrm{Lv}(4.34 \mathrm{mg} / \mathrm{kg} \mathrm{LW})$ in an f:c ratio (70: 30) diet for goats. This was consistent with results by Candyrine et al. [37], who found that replacing up to $26.3 \%$ of PKC by fermented PKC (to obtain a dose of Lv $6 \mathrm{mg} / \mathrm{kg} \mathrm{LW}$ ) in an f:c ratio diet (77:23) did not negatively affect the digestibility of DM. In this context, Mohd Azlan et al. [35] observed that fermented rice straw increased the digestibility of DM by $13 \%(P<0.05)$ in goats fed a diet containing $82 \%$ of neutral detergent fiber. Also, this experiment showed that the $A$. terreus strain degraded hemicellulose components of the fermented rice straw during the SSF bioprocess. An increase in the digestibility might be due to the production of enzymes cellulases, xylanases, and phenoloxidases by $A$. terreus strains, which would enhance the digestion of structural carbohydrates from lignocellulose feeds $[57,58]$.

Despite this, in vitro and in vivo trials showed that pure $\mathrm{Lv}$ and simvastatin $(100 \mathrm{mg} / \mathrm{L}$ culture media and $1.06 \mathrm{mg} /$ kg LW ) did not affect the nutrient digestibility of diets containing 70 and $48 \%$ of forage, respectively $[43,48]$.

In terms of $\mathrm{pH}$ and concentration of ammonia nitrogen, no effects were observed from the inclusion of pure $\mathrm{Lv}$ or fermented rice to ruminant rations under in vivo conditions $[48,50]$.

\section{Effect of lovastatin on rumen microbiota}

Initial work in rumen microbiology focused primarily on cultivating bacteria for a comprehensive understanding of fermentative metabolism [59, 60]. Afterward, cultured or uncultured microorganisms were subjected to molecular genetic methods to identify and quantify [61]. More recently, the meta-omic integration methodology has provided a more useful characterization of microbiomes (e.g., to identity microbial and predictive metabolomic profile) [62-64].

Within this framework, only three works have evaluated Lv impacts on rumen microbiota using highthroughput sequencing technology [31, 37, 50].

Candyrine et al. [37] assessed the rumen archaea and bacteria composition of goats when fermented PKC inhibited methanogenesis. They found that this did not affect the $\alpha$ (Simpson, Shannon, and Chao 1) and $\beta$ diversity indices (Principal Coordinate Analysis using Bray-Curtis dissimilarity) concerning the relative abundances of rumen microbiota. Unfortunately, biostatistical analyses were not reported. These results were consistent with those reported by Ábrego-García [31], who observed no significant differences in the $\alpha$ and $\beta$ diversity indices. However, the authors observed some evidence of differences between selected microbial abundances of the fermented oat straw as an Lv-carrier $(150 \mathrm{mg} / \mathrm{L})$ and the control groups. For instance, Prevotella abundance was significantly reduced. The abundances of the Ruminococcaceae family and the genus Ruminococcus were increased $(P<0.05)$, whereas the Euryarchaeota phylum was reduced by $38 \%$.

The experiment of Wang et al. [50] was limited to the rumen archaea composition. They reported that the Chao 1 alpha diversity was not affected; however, the Shannon-Wiener index was higher in the RYR treatment. Furthermore, the relative abundance of Methanobrevibacter was significantly decreased but increased in genus Methanomicrobium for the anti-methanogenic treatment. Due to the limited studies on this topic, the information regarding rumen microbial diversity was organized as classic and molecular biology techniques and discussed below.

As expected, in vivo and in vitro trials demonstrated that populations of archaea and total methanogens, as well as Methanobacteriales, were reduced $(P<0.05)$ when methanogenesis also declined due to the $\mathrm{Lv}$ treatments [34-36].

\section{Rumen bacteria}

The effectiveness of fermented rice straw and fermented rice supplements mixed with diets for small ruminants (doses of Lv 4.14 and $2.26 \mathrm{mg} / \mathrm{kg} \mathrm{LW}$ ) showed an increase $(P<0.05)$ in the concentration of rumen bacteria of sheep and goats, respectively $[35,36]$. These findings were congruent with those of Soliva et al. [40], who used pure $\mathrm{Lv}(150 \mathrm{mg} / \mathrm{L})$ for in vitro ruminal fermentation and demonstrated an increase in the bacteria population. However, Jahromi et al. [34] for in vitro experiments reported a significant decrease in the rumen bacteria population with fermented rice straw and extracts of this fermented substrate as treatments for methane mitigation.

\section{Cellulolytic/fibrinolytic bacteria}

No inhibitory effect of pure Lv on the concentration of cellulolytic/fibrinolytic bacteria was observed. This fact was initially established in cultures of $B$. fibrisolvens, $R$. albus, R. flavefasciens, F. succinogenes, and S. ruminantium with a dose of $4 \mathrm{mg} / \mathrm{L}$ culture medium [26]. Nevertheless, a possible increase in cellulolytic/fibrinolytic bacteria in the rumen was only associated with fermented agricultural residues as Lv carriers. For instance, Mohd Azlan et al. [35] reported that the R. albus population increased (cells $/ \mathrm{mL}$ ) three times over with an $\mathrm{Lv}$ dose of $4.14 \mathrm{mg} / \mathrm{animal} / \mathrm{d}$ in goats. In another study into in vitro methane mitigation, it was determined that the concentration of $R$. albus increased $(P<0.05)$, but F. succinogenes was reduced with a dose of $\mathrm{Lv} 4.3 \mathrm{mg} / \mathrm{L}$ RFI medium [34]. 


\section{Fungi}

There is no general agreement about the effect of Lv on rumen fungi. Detailed examination of works by Soliva et al. [40] and Jahromi et al. [34] demonstrated a significant decrease in anaerobic fungi when methanogenesis was significantly inhibited using pure $\mathrm{Lv}(150 \mathrm{mg} / \mathrm{L})$ and fermented rice straw as an $\mathrm{Lv}$-carrier $(4.3 \mathrm{mg} / \mathrm{L})$, respectively. However, a ten-fold increase in the anaerobic fungus population was observed with the fermented rice straw treatment (dose of $\mathrm{Lv} 4.14 \mathrm{mg} / \mathrm{kg} \mathrm{LW}$ ) compared to the control group in goats [35].

\section{Protozoa}

Mohd Azlan et al. [35] and Morgavi et al. [36] carried out series of experiments to mitigate methane production with fermented rice and rice straw treatments produced by SSF with M. porpureus spp and A. terreus (doses of Lv 2.26 and $4.14 \mathrm{mg} / \mathrm{kg} \mathrm{LW}$ ) in sheep and goats, respectively. No statistically significant differences in the rumen protozoa population were found between the treatment and control groups in those studies. This result was also observed for in vitro trials with RFI from sheep. Fermented rice straw or ethanolic extracts of fermented rice straw were evaluated on the population of protozoa [34]. Finally, there were no reports in the open literature on the effects on the rumen protozoa population when methane inhibition was significantly reduced by pure Lv treatment.

\section{Conclusion}

Lv treatment had a strong anti-methanogenic effect on pure strains of MA. However, there are uncertainties about results for in vitro fermentation with complex substrates and RFI.

On the other hand, the SSF of agricultural residues is a bioprocess that can be adopted for Lv production at a low cost. Those fermented agricultural as Lv-carriers fed to ruminants demonstrated a reliable decrease in ruminal methane emission. However, a remarkable feature of the currently available literature is the lack of positive control (pure Lv) in animal experiments.

The experimental evidence for in vitro trials showed that the VFA production was not affected by Lv; however, the results from in vivo trials demonstrated that production of VFA was decreased. The in vitro and in vivo DM digestibility was not negatively affected by Lv.

Regarding rumen microbiota, no differences were detected in alpha and beta diversity associated with $\mathrm{Lv}$ treatment, but it induced some changes in the relative abundance. Lv did not have an inhibitory effect on ruminal eubacteria but, there is insufficient evidence to determine its relationship to fungi and ruminal protozoa.

Additionally, further research is needed on the following issues: $(i) \mathrm{Lv}$ biodegradation products and stability, as well as its adsorption onto the solid matter in the rumen, should be assessed to determine the "available" or effective Lv concentration, and (ii) to assess whether the effect of $\mathrm{Lv}$ on ruminal fermentation also depends on the feed composition and different ruminants.

\section{Abbreviations}

DM: Dry matter; DMD: Dry matter digestibility; f:c ratio: Fiber to concentrate ratio; GHG: Greenhouse gas; HMG-CoA: 3-Hydroxy-3-methylglutaryl CoA; LV: Lovastatin; LW: Live weight; MA: Methanogenic archaea; PKC: Palm kernel cake; RFI: Rumen fluid inoculum; RYR: Red yeast rice; SSF: Solid-state fermentation; VFA: Volatile fatty acids

\section{Acknowledgments}

A graduate scholarship to A. Ábrego-García from CONACYT is acknowledged (CV: 337183).

\section{Authors' contributions}

AAG and HMPV conceptualized, carried out the literature review, and manuscript writing; TPN, GCC, VRG, DEB, ERL, and AMV revised the manuscript and accomplished final proofreading. All authors read and approved the final version of the manuscript.

\section{Funding}

This research was funded by Basic Science Project SEP-CONACYT (grant number A1-S-26901). Partial funding from a personal grant of Dr. Héctor M. Poggi-Varaldo to the Environmental Biotechnology and Renewable Energies through CINVESTAV is appreciated.

\section{Availability of data and materials \\ None.}

\section{Declarations}

Ethics approval and consent to participate

Not applicable.

Consent for publication

Not applicable.

\section{Competing interests}

The authors declare that they have no competing interests.

\section{Author details}

${ }^{1}$ Department of Biotechnology and Bioengineering, CINVESTAV-IPN, P.O.Box 17-740, 07000 Mexico City, Mexico. ${ }^{2}$ Environmental Biotechnology and Renewable Energies Group, CINVESTAV-IPN, P.O.Box 17-740, 07000 Mexico City, Mexico. ${ }^{3}$ Instituto de Hidrología, Universidad Tecnológica de la Mixteca, Oaxaca 69000 Huajuapan de León, Mexico. ${ }^{4}$ National Collection of Microbial and Cellular Cultures, CINVESTAV-IPN, P.O.Box17-740, 07000 Mexico City, Mexico. ${ }^{5}$ Unidad de Secuenciación e Identificación de Polimorfismos, Instituto Nacional de Medicina Genómica, 14610 Mexico City, Mexico.

Received: 30 May 2021 Accepted: 3 October 2021

Published online: 16 December 2021

\section{References}

1. Ripple WJ, Smith P, Haberl H, Montzka SA, McAlpine C, Boucher DH Ruminants, climate change and climate policy. Nat Clim Chang. 2014;4(1):25. https://doi.org/10.1038/nclimate2081.

2. Herrero M, Henderson B, Havlík P, Thornton PK, Conant RT, Smith $P$, et al. Greenhouse gas mitigation potentials in the livestock sector. Nat Clim Chang. 2016;6(5):452-61. https://doi.org/10.1038/nclimate2925.

3. Victor DG, et al. Introductory chapter. In: Edenhofer $\mathrm{O}$, et al., editors. Climate change 2014: mitigation of climate change. Contribution of working group III to the fifth assessment report of the intergovernmental panel on climate change: 2014. Cambridge: Cambridge University Press; 2014. p. 111-50.

4. Saunois M, Stavert AR, Poulter B, Bousquet P, Canadell JG, Jackson RB, et al. The global methane budget 2000-2017. Earth Syst Sci Data. 2020;12(3): 1561-623. https://doi.org/10.5194/essd-12-1561-2020. 
5. Gerber PJ, Steinfeld H, Henderson B, Mottet A, Opio C, Dijkman J, et al Implications for policy-marking. Tackling Climate Change through LivestockA global assessment of emissions and mitigation opportunities. Rome: Food and Agriculture Organization of the United Nations (FAO); 2013.

6. Owens FN, Basalan M. Ruminal fermentation. In: Millen D, De Beni Arrigoni M, Lauritani Pacheco RD, editors. Rumenology. Switzerland: Springer International Publish; 2016. p. 63-103. https://doi.org/10.1007/978-3-319-3 0533-2 2 .

7. Tapio I, Snelling TJ, Strozzi FWR. The ruminal microbiome associated with methane emissions from ruminant livestock. J Anim Sci Biotechnol. 2017;8:7. https://doi.org/10.1186/s40104-017-0141-0.

8. Johnson KA, Jhonson DE. Methane emissions from cattle. J Anim Sci. 1995 73(8):2483-92. https://doi.org/10.2527/1995.7382483x

9. Patra A, Park T, Kim M, Yu Z. Rumen methanogens and mitigation of methane emission by anti-methanogenic compounds and substances. J Anim Sci Biotechnol. 2017:8:13. https://doi.org/10.1186/s40104-017-01459.

10. Beauchemin KA, Ungerfeld EM, Eckard RJ, Wang M. Review: fifty years of research on rumen methanogenesis: lessons learned and future challenges for mitigation. Animal. 2020;14 Suppl 1:S2-S16. https://doi.org/10.1017/S1 751731119003100

11. Mahdavi A, Bagherniya M, Fakheran O, Reiner Ž, Xu S, Sahebkar A. Medicinal plants and bioactive natural compounds as inhibitors of HMG-CoA reductase: a literature review. BioFactors. 2020;46(6):906-26. https://doi.org/1 0.1002/biof.1684

12. Jain S, Caforio A, Driessen AJ. Biosynthesis of archaeal membrane ether lipids. Front Microbiol. 2014:5:641. https://doi.org/10.3389/fmicb.2014.00641.

13. Goopy JP. Creating a low enteric methane emission ruminant: what is the evidence of success to the present and prospects for developing economies? Anim Prod Sci. 2019;59(10):1769-76. https://doi.org/10.1071/A N18457.

14. Haque MN. Dietary manipulation: a sustainable way to mitigate methane emissions from ruminants. J Anim Sci Technol. 2018;60:15. https://doi.org/1 0.1186/s40781-018-0175-7.

15. Konings WN, Albers SV, Koning S, Driessen AJ. The cell membrane plays a crucial role in survival of bacteria and archaea in extreme environments. Antonie Van Leeuwenhoek. 2002;81(1/4):61-72. https://doi.org/10.1023/a:1 020573408652

16. Sûstar V, Zelko J, Lopalco P, Lobasso S, Ota AUN. Morphology, biophysical properties and protein mediated fusion of Archaeosomes. PLoS One. 2012; 7(7):1-15. https://doi.org/10.1371/journal.pone.0039401.

17. Vickers CE, Sabri S. Isoprene. Adv Biochem Engin/Biotechnol. 2015;148:289_ 317. https://doi.org/10.1007/10_2014_303.

18. Knappy CS, Nunn CE, Morgan HW, Keely BJ. The major lipid cores of the archaeon Ignisphaera aggregans: implications for the phylogeny and biosynthesis of glycerol monoalkyl glycerol tetraether isoprenoid lipids. Extremophiles. 2011;15(4):517-28. https://doi.org/10.1007/s00792-011-03 82-3

19. Goswami S, Vidyarthi AS, Bhunia BMT. A review on lovastatin and its production. J Biochem Tech. 2012;4(1):581-7.

20. Subhan M, Faryal R, Macreadie I. Exploitation of Aspergillus terreus for the production of natural statins. J Fungi. 2016;2(2):13. https://doi.org/10.3390/ jof2020013.

21. Salvador-Castell M, Tourte M, Oger PM. In search for the membrane regulators of archaea. Int J Mol Sci. 2019;20(18):4434. https://doi.org/10.33 90/ijms20184434.

22. Wu Y, Xiong F, Chen F. Stereoselective synthesis of 3-hydroxy-3methylglutaryl- coenzyme a reductase inhibitors. Tetrahedron. 2015;71(45): 8487-510. https://doi.org/10.1016/j.tet.2015.07.059.

23. Ying J, Du LD, Du GH. Lovastatin. In: Du G-H, editor. Natural small molecule drugs from plants. Singapore: Springer; 2018. p. 93-9. https://doi.org/10.1 007/978-981-10-8022-7_15.

24. Matsumi R, Atomi H, Driessen AJM, van der Oost J. Isoprenoid biosynthesis in Archaea - biochemical and evolutionary implications. Res Microbiol. 2011;162(1):39-52. https://doi.org/10.1016/j.resmic.2010.10.003.

25. Gottlieb K, Wacher V, Sliman J, Pimentel M. Review article: inhibition of methanogenic archaea by statins as a targeted management strategy for constipation and related disorders. Aliment Pharmacol Ther. 2016;43(2):197212. https://doi.org/10.1111/apt.13469.

26. Miller TL, Wolin MJ. Inhibition of growth of methane-producing bacteria of the ruminant forestomach by hydroxymethylglutaryl-SCOA reductase inhibitors. J Dairy Sci. 2001;84(6):1445-8. https://doi.org/10.3168/jds.S0022-03 02(01)70177-426.

27. Jahromi MF, Liang J, Ho YW, Mohamad R, Goh YM, Shokryazdan P, et al Lovastatin in Aspergillus terreus: fermented rice straw extracts interferes with methane production and gene expression in Methanobrevibacter smithii. Biomed Res Int. 2013;2013:604721. https://doi.org/10.1155/2013/604 721.

28. Sharma A, Chaudhary P, Sirohi S, Saxena J. Structure modeling and inhibitor prediction of NADP oxidoreductase enzyme from Methanobrevibacter smithii. Bioinformation. 2011;6(1):15-9. https://doi.org/10.6026/9732063 0006015.

29. Muskal SM, Sliman J, Kokai-Kun J, Pimentel M, Wacher V, Gottlieb K. Lovastatin lactone may improve irritable bowel syndrome with constipation (IBS-C) by inhibiting enzymes in the archaeal methanogenesis pathway. F1000Res. 2016:8(5):606. https://doi.org/10.12688/f1000research.8406.3.

30. Mulder KC, Mulinari F, Franco OL, Soares MS, Magalhães BS, Parachin NS. Lovastatin production: from molecular basis to industrial process optimization. Biotechnol Adv. 2015;1(33):648-65. https://doi.org/10.1016/j. biotechadv.2015.04.001.

31. Ábrego-García A, Poggi-Varaldo HM, Mendoza-Vargas A, Mercado-Valle FGR-LE, Ponce-Noyola T, Calva-Calva G. Effects of fermented oat straw as a lovastatincarrier on in vitro methane production and rumen microbiota. Front Energy Res. 2021;9:630701. https://doi.org/10.3389/fenrg.2021.630701 .

32. Godoy MG, Amorim GM, Barreto MS, Freire DMG. Chapter 10: Agricultural residues as animal feed: Protein enrichment and detoxification using solidstate fermentation. In: Pandey A, Larroche C, Soccol C, editors. Current Developments in Biotechnology and Bioengineering. New York: Current Advances in Solid-State Fermentation Elseiver Inc; 2018. p. 235-56.

33. Varadyova Z, Certik M, Jalc D. The possible application of fungal enriched substrates in ruminant nutrition. A review. J Anim Feed Sci. 2018;27(1):3-10. https://doi.org/10.22358/jafs/84787/2018.

34. Jahromi MF, Liang JB, Mohamad R, Goh YM, Shokryazdan P, Ho YW. Lovastatin-enriched rice straw enhances biomass quality and suppresses ruminal methanogenesis. Biomed Res Int. 2013;2013:1-13. https://doi.org/1 $0.1155 / 2013 / 397934$

35. Mohd Azlan P, Jahromi MF, Ariff MO, Ebrahimi M, Candyrine SCL, Liang JB. Aspergillus terreus treated rice straw suppresses methane production and enhances feed digestibility in goats. Trop Anim Health Prod. 2018;50(3):56571. https://doi.org/10.1007/s11250-017-1470-x.

36. Morgavi DP, Martin C, Boudra H. Fungal secondary metabolites from Monascus spp. reduce rumen methane production in vitro and in vivo. J Anim Sci. 2013;91(2):848-60. https://doi.org/10.2527/jas.2012-5665.

37. Candyrine SCL, Mahadzir MF, Garba S, Jahromi MF, Ebrahimi M, Goh YM, et al. Effects of naturally-produced lovastatin on feed digestibility, rumen fermentation, microbiota and methane emissions in goats over a 12-week treatment period. PLoS One. 2018;13(7):e0199840. https://doi.org/10.1371/ journal.pone.0199840.

38. Demonfort Nkamga V, Armstrong N, Drancourt M. In vitro susceptibility of cultured human methanogens to lovastatin. Int J Antimicrob Agents. 2017; 49(2):176-82. https://doi.org/10.1016/j.ijantimicag.2016.09.026.

39. Busquet M, Calsamiglia S, Ferret A, Carro MD, Kamel C. Effect of garlic oil and four of its compounds on rumen microbial fermentation. J Dairy Sci. 2005;88(12):4393-404. https://doi.org/10.3168/jds.S0022-0302(05)73126-X.

40. Soliva CR, Amelchanka SL, Duval SM, Kreuzer M. Ruminal methane inhibition potential of various pure compounds in comparison with garlic oil as determined with a rumen simulation technique (Rusitec). Br J Nutr. 2011; 106(01):114-22. https://doi.org/10.1017/S0007114510005684.

41. O'Brien M, Navarro-Villa A, Purcell PJ, Boland T, O'kiely P. Reducing in vitro rumen methanogenesis for two contrasting diets using a series of inclusion rates of different additives. Anim Prod Sci. 2014;54(2):141-57. https://doi. org/10.1071/AN12204.

42. Khonkhaeng B, Cherdthong A. Improving nutritive value of purple field corn residue and Rice straw by culturing with white-rot Fungi. J Fungi. 2020;6(2): 69. https://doi.org/10.3390/jof6020069.

43. Joch $M$, Vadroňová M, Výborná A, Jochová K. Inhibition of in vitro rumen methane production by three statins. Ann Anim Sci. 2021. https://doi.org/1 0.2478/aoas-2021-0022.

44. Monson PA. Understanding adsorption/desorption hysteresis for fluids in mesoporous materials using simple molecular models and classical density functional theory. Micropor Mesopor Mat. 2012;160:47-66. https://doi.org/1 0.1016/j.micromeso.2012.04.043. 
45. Sathya V, Sinduja M, Kalpana P, Maheswari M, Ramasubramaniyan MR, Mahimairaja S. Strategic study of adsorption and desorption of chromium on vertisols and its implication in developing an effective remediation technology. Int J Environ Anal Chem. 2021. https://doi.org/10.1080/0306731 9.2021.1940985

46. Poggi-Varaldo HM, Rinderknecht-Seijas N, Caffarel-Méndez S. Irreversibilidad en el comportamiento adsortivo-desortivo de contaminantes en suelos y sedimentos: evaluación cuantitativa por medio de un coeficiente de histéresis diferencial. Interciencia. 2002;27(4):191-4.

47. Robles-González IR, Ríos-Leal E, Galíndez-Mayer JM, Caffarel-Méndez S, Barrera-Cortés J, Esparza-García F, et al. Adsorptive-desorptive behaviour of lindane in an agricultural soil. Interciencia. 2006;31(4):305-8.

48. Klevenhusen F, Duval S, Zeitz JO, Kreuzer M, Soliva CR. Diallyl disulphide and lovastatin: effects on energy and protein utilisation in, as well as methane emission from, sheep. Arch Anim Nutr. 2011;65(4):255-66. https://doi.org/1 0.1080/1745039x.2011.588845.

49. Ramírez-Restrepo CA, O'neill CJ, López-Villalobos N, Padmanabha J, Mcsweeney C. Tropical cattle methane emissions: the role of natural statins supplementation. Anim Prod Sci. 2014;54(9):1294-9. https://doi.org/10.1 071/AN14246

50. Wang LZ, Zhou ML, Wang JW, Wu D, Yan T. The effect of dietary replacement of ordinary rice with red yeast rice on nutrient utilization, enteric methane emission and rumen archaeal diversity in goats. PLoS One. 2016;11(7):1-14. https://doi.org/10.1371/journal.pone.0160198.

51. Leo TK, Garba S, Abubakar D, Sazili AQ, Candyrine SCL, et al. Naturally produced lovastatin modifies the histology and proteome profile of goat skeletal muscle. Animals. 2020;10(1):72. https://doi.org/10.1101/581439.

52. Kajdič S, Zupančič $S$, Roškar $R$, Kocbek P. The potential of nanofibers to increase solubility and dissolution rate of the poorly soluble and chemically unstable drug lovastatin. Int J Pharm. 2019;573:118809. https://doi.org/10.1 016/j.jpharm.2019.118809.

53. Syed MB, Ponnusamy T. Bioconversion of mevastatin to pravastatin by various microorganisms and its applications-a review. Biocatal Agric Biotechnol. 2018;13:62-74. https://doi.org/10.1016/j.bcab.2017.11.002.

54. Zhang Y, Zhang H, Che E, Zhang L, Han J, Yang Y, et al. Development of novel mesoporous nanomatrix-supported lipid bilayers for oral sustained delivery of the water-insoluble drug, lovastatin. Colloids Surf B Biointerfaces. 2015;128:77-85. https://doi.org/10.1016/j.colsurfb.2015.02.021.

55. Qiao L, Xie D, Liu Q, Zou J, Shen Z, Dai J. Microbial transformation of lovastatin by Beauveria bassiana. Acta Pharm Sin B. 2012;2(3):300-5. https:// doi.org/10.1016/j.apsb.2012.04.001.

56. Beltrán D, Frutos-Lisón MD, Espín JC, García-Villalba R. Re-examining the role of the gut microbiota in the conversion of the lipid-lowering statin monacolin K (lovastatin) into its active $\beta$-hydroxy acid metabolite. Food Funct. 2019;10(4):1787-91. https://doi.org/10.1039/c8fo02594k.

57. Abrão FO, Duarte ER, Pessoa MS, Dos Santos VL, De Freitas LF, Barros KDO, et al. Notable fibrolytic enzyme production by Aspergillus spp. isolates from the gastrointestinal tract of beef cattle fed in lignified pastures. PLoS One. 2017;12(8):1-13. https://doi.org/10.1371/journal.pone.0183628.

58. Londoño-Hernandez L, Ruiz HA, Toro CR, Ascacio-Valdes A, RodriguezHerrera R, Aguilera-Carbo A, et al. Advantages and Progress innovations of solid-state fermentation to produce industrial enzymes. In: Arora N, Mishra J, Mishra $V$, editors. Microbial enzymes: roles and applications in industries. Microorganisms for sustainability, vol. 11. Singapore: Springer; 2020. p. 87113. https://doi.org/10.1007/978-981-15-1710-5_4.

59. Hungate RE, Bryant M, Mah RA. The rumen Bacteria and Protozoa. Annu Rev Microbiol. 1964;18(1):131-66. https://doi.org/10.1146/annurev.mi.18.100164. 001023.

60. Hobson PN. Rumen Bacteria. Methods Microbiol. 1969:133-49. https://doi. org/10.1016/S0580-9517(08)70504-X.

61. Knight IT. Molecular genetic methods for detection and identification of viable but Nonculturable. In: Colwell RR, Grimes D, editors. Microorganisms Nonculturable microorganisms in the environment. Boston: Springer; 2000. p. 77-85. https://doi.org/10.1007/978-1-4757-0271-2_6.

62. Muller EEL, Faust K, Widder S, Herold M, Martínez Arbas S, Wilmes P. Using metabolic networks to resolve ecological properties of microbiomes. Curr Opin Syst Biol. 2018;8:73-80. https://doi.org/10.1016/j.coisb.2017.12.004.

63. Gharechahi J, Vahidi MF, Bahram M, Han JL, Ding XZ, Salekdeh GH. Metagenomic analysis reveals a dynamic microbiome with diversified adaptive functions to utilize high lignocellulosic forages in the cattle rumen. ISME J. 2021;15(4):1108-20. https://doi.org/10.1038/s41396-020-00837-2.
64. He B, Jin S, Cao J, Mi L, Wang J. Metatranscriptomics of the Hu sheep rumen microbiome reveals novel cellulases. Biotechnol Biofuels. 2019;12(1): 153. https://doi.org/10.1186/s13068-019-1498-4.

\section{Ready to submit your research? Choose BMC and benefit from:}

- fast, convenient online submission

- thorough peer review by experienced researchers in your field

- rapid publication on acceptance

- support for research data, including large and complex data types

- gold Open Access which fosters wider collaboration and increased citations

- maximum visibility for your research: over $100 \mathrm{M}$ website views per year

At BMC, research is always in progress.

Learn more biomedcentral.com/submissions 